\title{
EVALUATION OF THE PHYTOCHEMICAL COMPOSITIONS AND ANTIOXIDANT ACTIVITY OF PEPPER FRUIT (Dennettia tripetala) SEEDS AND PEELS
}

A. Odia

Department of Chemistry, Faculty of Physical Sciences, Ambrose Alli University, P.M.B. 14 Ekpoma, Edo State, Nigeria.

ABSTRACT-The phytochemical screening and antioxidant activities of pepper fruit (Dennettia tripetala) were studied. Four different solvents; methanol, ethanol, butanol and water were used for the extractions for the phytochemicals assay which revealed that the seeds and peels of the unripe and ripe pepper fruit (Dennettia tripetala) contains significant amount of these plant chemicals. The quantitative phytocehmical and antioxidant activities was assayed by investigating their 2,2-diphenyl-1-picrylhydrazyl (DPPH) radical scavenging activity, reducing power, hydrogen peroxide $\left(\mathrm{H}_{2} \mathrm{O}_{2}\right)$ scavenging activity, hydroxyl radical scavenging activity, total flavonoid, alkaloid and total phenolic content. DPPH radical scavenging activity for the seeds of ripe pepper fruit was the highest $(82.46 \pm 0.16 \%)$ and the lowest value $(76.95 \pm 0.17$ $\%$ ) was recorded for the peel of the ripe fruit. The peel and seeds of the unripe pepper fruit had $80.09 \pm 0.30 \%$ and $80.53 \pm 0.21 \%$ respectively. For the reducing power activity, the unripe peel $76.34 \pm 0.61 \%$, ripe peel $68.45 \pm 0.23 \%$, the ripe and unripe seeds having $69.08 \pm 2.23 \%$ and $73.66 \pm 1.88 \%$ respectively. The hydrogen peroxide $\left(\mathrm{H}_{2} \mathrm{O}_{2}\right)$ scavenging activity for the ripe peel $5.60 \pm 0.62 \%$ was the lowest while unripe peel $30.67 \pm 1.13 \%$ was the highest. Hydroxyl radical activities of Dennetia tripetala revealed that the ripe peel had $17.23 \pm 0.58 \%$, the unripe

\author{
G.E. Irabor \\ Department of Chemistry, Faculty of Physical \\ Sciences, Ambrose Alli University, \\ P.M.B. 14 Ekpoma, Edo State, Nigeria.
}

peel $15.61 \pm 0.58 \%$, the ripe fruit seeds $4.58 \pm 2.02$ $\%$ and the unripe seeds had $28.00 \pm 3.40 \%$ while flavonoids contents had a range of $74.03 \pm 0.78$ $75.66 \pm 0.38 \%$. Alkaloid however recorded $0.19 \pm$ $0.01 \mathrm{mg} / 100 \mathrm{~g}$ for the unripe seed as the highest value while the ripe peel recorded $0.16 \pm 0.02$ $\mathrm{mg} / 100 \mathrm{~g}$ as the lowest.

Keyword: Antioxidant, phytochemical, scavenging activity, Butylatedhydroxytoluene and Dennettia tripetala.

\section{INTRODUCTION}

The use of plant and plant parts for curative purposes have been on the increase as they have show great potentials in reducing and in some cases result total cure to illments. Various part such as leaves, fruits, seeds, bark, flowers, rhizomes and root have at one time or the other been utilized for these medicinal purpose. Fruit and vegetable intake is the focus of widespread research interest in health (Thompson et al., 2011). They have historically held a place in dietary guidance because of their concentration of vitamins, especially vitamin $\mathrm{C}$ and A; minerals, especially electrolytes; and more recently, phytochemicals, especially antioxidants (Slavin and Lloyd, 2012).

Nowadays, there is noticeable interest in antioxidants and phytochemicals. Antioxidants of interest include those which can prevent the 


\section{International Journal of Engineering Applied Sciences and Technology, 2020 Vol. 5, Issue 2, ISSN No. 2455-2143, Pages 60-68 \\ Published Online June 2020 in IJEAST (http://www.ijeast.com)}

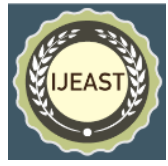

presumed deleterious effects of free radicals in the human body, and to prevent the deterioration of fats and other constituents of food stuffs. In both cases, there is a preference for antioxidants from natural rather than from synthetic sources (Molyneux, 2004). The main disadvantage with the synthetic antioxidants is their side effects invivo (Ramamoorthy and Bono, 2007). Infections caused by strains of bacteria that are resistant to orthodox drugs, also called multi-drug resistance (MDR) bacteria, have either found cure or control by the use of bioactive compounds (phytochemicals) isolated from plants. They can help prevent the spread of or totally eliminated infections and diseases.

Dennettia tripetala commonly known as pepper fruit tree is a plant found mostly in tropical Africa, especially in southern, eastern and western Nigeria. Dennettia tripetala tree is a woody plant of at least 3 meters height with simple leaves and abundant fruits widely consumed in southern Nigeria. The Igbos calls it Nmimi, Ibibio and Efik people call it nkaika, Urhobo call it imako, Yorubas call it ata igbere while the Edos call it ako (Isegholi, 2015). The leaves, fruits and roots of the plant possess strong peppery and pungent spicy taste with a characteristic aroma and fragrance. The fruits and leaves are used as seasoning in preparing foods such as meat, soup and in some local dish because of their instinctive spicy taste. Some communities in parts of southern Nigeria also utilized the leaves and roots in addition to the fruits for medicinal purposes (Adebayo et al., 2010).

Elekwa et al. (2011) phytochemicals screening of the ethanolic extract revealed the presence of tannins, alkaloids, steroids, flavonoids, cardac glycosides, saponins, and terpenoids. These constituents provided a scientific basis for the use of Dennettia tripetala in traditional medicine. Saponins, tannins and flavonoids for instance, are effective against diabetes. They possess antimicrobial and anti-inflammatory properties. Researchers have shown that the fruits of Dennetia tripetala when dried consist of carbohydrates (Okwu and Morah, 2004). Dennetia tripetala also contain protein, fibre, ash, lipids and moisture. Dennetia tripetala also coantains trace elements, minerals, and water-soluble vitamins (Okwu and Morah, 2004). These vitamin A and $\mathrm{C}$ tend to increase significantly with ripening (Ihemeje et al.,
2013). The peppery fruit of Dennettia tripetala are applied to food meant for pregnant women and are important in the diet post partum women during which time it is claimed that spices and herbs aid uterine contraction (Okwu and Morah, 2004).

This study investigated the antioxidant and phytochemical compositions of the peels and seeds of the ripe and unripe pepper fruit (Dennettia tripetala).
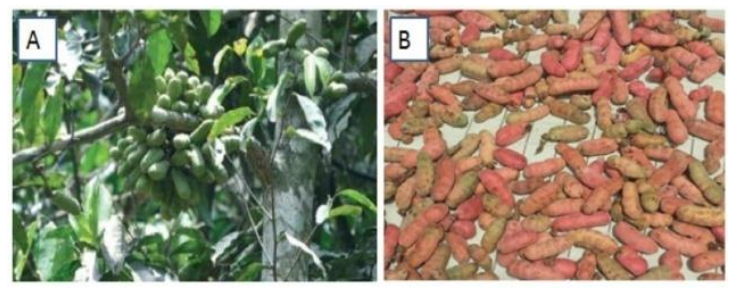

Fig. 1: (A) Dennettia tripetala tree with leaves and unripe fruits. (B) Ripe (red) and unripe (green) Dennettia tripetala fruits. (World Agroforestry Center and Rubber Research Institute of Nigeria) (Sylvia, 2015).

\section{MATERIALS AND METHODS}

\section{A. Sample Collection and Preparation}

Fresh unripe and ripe pepper fruit used for this study were purchased from new market in Ekpoma, Esan West Local Government Area, Edo State. The fresh pepper fruit (ripe and unripe) seeds were carefully separated from the pulp (peels) using a kitchen knife. After removing the seeds, the fresh pulp (peel) along with the seeds were separately dried with laboratory oven at $105{ }^{\circ} \mathrm{C}$ for two hours each. The dried seeds and peel were then blended into fine powder using an electronic blender and the pulverized samples were stored in air tight clean containers.

\section{B. Extraction For Phytochemicals Analysis}

The pulverized sample was extracted separately with methanol, ethanol, butanol, and distilled water. 10 gram portion each was weighed and separately dispersed in $100 \mathrm{ml}$ of each solvent. Each of the solution was shaken for $3 \mathrm{hrs}$ with an adjustable vibrating shaker at room temperature. On completion of the shaking, the mixture was left to stand at room temperature for 24 hours after which it 
was filtered with whatman No. 1 filter paper, the filtrate was used for the analysis.

\section{Extraction For Antioxidants Analysis}

Ten grams of the respective plant powder was weighed into a conical flask and $200 \mathrm{ml}$ of distilled water was added. It was left for 2 hours and filtered with whatman No.1 filter paper. The filtrate was then used for the antioxidant analysis.

\section{Qualitative Phytochemicals Screening}

The various extracts were tested for the presence of phenols, tannis, terpenoid, Alkaloids, Saponins, flavonoid, sterols and glycosides using standard methods described by Trease and Evans, (2002)

\section{E. Antioxidants analysis}

\section{Determination of Total Flavonoid Content}

The total flavonoid content was determined with aluminium chloride $\left(\mathrm{AlCl}_{3}\right)$ using quercetin as a standard. The plant extract $(0.1 \mathrm{ml})$ was added to 0.3 $\mathrm{ml}$ distilled water followed by $\mathrm{NaNO}_{2}(0.03 \mathrm{ml}$, $5 \%)$. After $5 \mathrm{~min}$ at $25^{\circ} \mathrm{C}, \mathrm{AlCl}_{3}(0.03 \mathrm{ml}, 10 \%)$ was added. After a further $5 \mathrm{~min}$, the reaction mixture was treated with $0.2 \mathrm{ml} 1 \mathrm{mM} \mathrm{NaOH}$. Finally, the reaction mixture was diluted to $1 \mathrm{ml}$ with water and the absorbance was measured at $510 \mathrm{~nm}$. All test were performed in triplicate. The total flavonoid content was calculated from quercetin standard graph (Zhishen et al., 1999).

\section{Determination of Total Phenolic Content}

Total phenolic content of the extracts were determined using Folin-Ciocalteu (FC) reagent. $1 \mathrm{ml}$ of the plant extract was mixed with $0.75 \mathrm{ml}$ of Folin-Ciocauteu reagent (previously diluted 1000 fold with distilled water) and was incubated for 5 min at $22{ }^{\circ} \mathrm{C}$ then $3 \mathrm{ml}$ of $0.06 \% \mathrm{Na}_{2} \mathrm{CO}_{3}$ solution was added and then allowed to incubate for 90 minutes. The absorbance was measured at $725 \mathrm{~nm}$. All tests were performed in triplicate. The Phenolic content was evaluated from a gallic acid standard curve.

\section{Determination of DPPH Radicals Scavenging Activity}

$2.0 \mathrm{ml}$ solution of the extract at different concentrations diluted two-fold in methanol was mixed with $1.0 \mathrm{ml}$ of $0.3 \mathrm{mM}$ DPPH in methanol.
The mixture was shaken vigorously and allowed to stand at room temperature in the dark for $25 \mathrm{~min}$. Blank solutions were prepared with each test sample solution $(2.0 \mathrm{ml})$ and $1.0 \mathrm{ml}$ of methanol while the negative control was $1.0 \mathrm{ml}$ of $0.3 \mathrm{mM} \mathrm{DPPH}$ solution plus $2.0 \mathrm{ml}$ of methanol. L-ascorbic acid was used as the positive control. Thereafter, the absorbance of the assay mixture was measured at $518 \mathrm{~nm}$ against each blank with a UV-visible spectrophotometer. DPPH radical inhibition was calculated using the equation (Awah et al., 2010):

$$
\% \text { Inhibition }=\frac{A_{\text {control }}-A_{\text {test }}}{A_{\text {control }}} \times \frac{100}{1}
$$

Where; $\mathrm{A}_{\text {control }}=$ is the absorbance of the control reaction, $A_{\text {test }}=$ is the absorbance in the presence of the sample of the extracts.

\section{Hydroxyl Radical Scavenging Activity Determination}

An aliquot of $50 \mathrm{mM}$ hydrogen peroxide $\left(\mathrm{H}_{2} \mathrm{O}_{2}\right)$ and various concentrations $(0-2 \mathrm{mg} / \mathrm{ml})$ of samples were mixed $(1: 1 \mathrm{v} / \mathrm{v})$ and incubated for 30 minutes at room temperature. After incubation, $90 \mu l$ of the $\mathrm{H}_{2} \mathrm{O}_{2}$-sample solution was mixed with $10 \mu l$ HPLCgrade methanol and $0.9 \mathrm{ml}$ FOX reagent was added (prepared in advance by mixing 9 volumes of 4.4 $\mathrm{mM}$ butylated hydroxyltoluene (BHT) in HPLCgrade methanol with 1 volume of $1 \mathrm{mM}$ xylenol and $2.56 \mathrm{mM}$ ammonium ferrous sulphate in $0.25 \mathrm{M}$ $\mathrm{H}_{2} \mathrm{SO}_{4}$ ). The reaction mixture was then vortexed and incubated at room temperature for 30 minutes. The absorbance of the ferric-xylenol orange complex was measured at $506 \mathrm{~nm}$. All test wascarried out three times and sodium pyruvate was used as the reference compound (Floriano-Sanchez et al., 2006).

$$
\text { Hydroxyl radical scavening activity }(\%)=\frac{\text { Absreference }- \text { Abs sample }}{\text { Absreferences }} \times 100
$$

Where: Abs references $=$ absorbance of the reference (reacting mixture without the test sample), Abs sample $=$ Absorbance of reacting mixture with the test sample

Determination of Hydrogen Peroxide Scavenging Activity 


\section{International Journal of Engineering Applied Sciences and Technology, 2020 \\ Vol. 5, Issue 2, ISSN No. 2455-2143, Pages 60-68 \\ Published Online June 2020 in IJEAST (http://www.ijeast.com)}

This was assayed using the method of Elizabeth and Rao, (1990) with a slight modification. The assay was based on quantification of the degradation product of 2-deoxyribose by condensation with TBA. Hydroxyl radical was generated by the $\mathrm{Fe}^{3+}-$ abscorbate. EDTA- $\mathrm{H}_{2} \mathrm{O}_{2}$ system (the febton reaction). The reaction mixture contained, in a final volume of $1 \mathrm{ml}$, 2-deoxy-2-ribose $(2.8 \mathrm{mM})$; $\mathrm{KH}_{2} \mathrm{PO}_{4}-\mathrm{KOH}$ buffer (20 mM, pH 7.4); $\mathrm{FeCl}_{3}(100$ $\mu M) ; \mathrm{H}_{2} \mathrm{O}_{2}(1.0 \mathrm{mM})$; ascorbic acid $(100 \mu M)$; $\operatorname{EDTA}(100 \mu M)$ and various concentrations $(0-200$ $\mu \mathrm{g} / \mathrm{ml}$ ) of the test sample or reference compound. After incubation for 1 hour at $37^{\circ} \mathrm{C}, 0.5 \mathrm{ml}$ of the reaction mixture ws incubated at $90{ }^{\circ} \mathrm{C}$ for 15 minutes to develop the colour. After cooling, the absorbance was measured at $532 \mathrm{~nm}$ against an appropriate blank solution. All test were performed in triplicate. Mannitol, a classical $\mathrm{OH}$ scavenger was used as a positive control. Percentage inhibition was evaluated by comparing the test and blank solutions.

$$
\% \text { Inhibition }=\frac{A_{\text {control }}-A_{\text {test }}}{A_{\text {control }}} \times \frac{100}{1}
$$

Where; $\mathrm{A}_{\text {control }}=$ is the absorbance of the control reaction, $A_{\text {test }}=$ is the absorbance in the presence of the sample of the extracts.

\section{Reducing Power Determination}

The iron (III) ion $\mathrm{Fe}^{3+}$-reducing power of the extract was determined by the method described by Oyaizu (1986) with a slight modification. Different concentrations $(0.0-0.4 \mathrm{mg} / \mathrm{ml})$ of the extract $(0.5$ $\mathrm{ml})$ were mixed with $0.5 \mathrm{ml}$ phosphate buffer $(0.2$ $\mathrm{M}, \mathrm{pH}$ 6.6) and $0.5 \mathrm{ml}$ potassium hexacyanoferrate $(0.1 \%)$, followed by incubation at $50^{\circ} \mathrm{C}$ in a water bath for $20 \mathrm{~min}$. After incubation, $0.5 \mathrm{ml}$ of TCA (10\%) Trichloroethanoic acid $\left(\mathrm{CCl}_{3} \mathrm{COOH}\right)$ was added to terminate the reaction. The upper portion of the solution $(1 \mathrm{ml})$ was mixed with $1 \mathrm{ml}$ distilled water, and $0.1 \mathrm{ml} \mathrm{FeCl}_{3}$ solution $(0.01 \%)$ was added. The reaction mixture was left for $10 \mathrm{~min}$ at room temperature and the absorbance was measured at $700 \mathrm{~nm}$ against an appropriate blank solution. All tests were performed three times. A higher absorbance of the reaction mixture indicated greater reducing power. Butylated hydroxytoluene (BHT) was used as a positive control. The reducing power concentrated was estimated using Abs * 0.129/0.003

\section{Total Alkaloid Determination}

About $10 \mathrm{~g}$ of each sample was weighed into a $250 \mathrm{ml}$ beaker and $20 \mathrm{ml}$ of $10 \%$ acetic acid in ethanol was added to it. A magnetic stirrer was used to mix the solution for 5hours at room temperature. The solution was filtered using whatman No 1 filter paper and the filtrate was place on a hot water bath (themostat) $\left(60^{\circ} \mathrm{C}\right)$ until the extract volume turned one-fourth of its initial volume. Concentrated ammonium hydroxide was added till the formation of the precipitate was complete. The whole solution was allowed to settle down and the precipitate was collected by filtration, dried in an oven (themostat) cooled in a dessicator then weighed. The process repeated three times for each of the samples (Obadani and Ochuko, 2001).

\section{RESULTS AND DISCUSSION}

Several studies have consistently reported that the medicinal properties of plants are largely attributable to their phytochemical and antioxidant contents. The phytochemical screening of the extracts of the peels and seeds of Dennettia tripetala using different solvents revealed the presence of the various secondary metabolites in varying degree and also according to how soluble they are in the various solvents used for the extraction as shown in Tables 1 below. Alcoholic solvents used revealed more presence of the phytochemicals as compared to water. The penetration of these alcoholic solvent is factored by the low densities and viscosities as compared to water. The observation was also reported by Oparanozie, 2015.

Several methods have been developed in recent years to calculate the total antioxidant activity of biological samples. Antioxidation activity represents the capability of scavenging free radical and offering hydrogen atom. Higher antioxidation activity indicates stronger capability. The quantitative phytochemical and antioxidants activities; 2,2-diphenyl-2-picrylhydrazyl (DPPH), hydrogen peroxide scavenging, total Phenolic content, reducing power, hydroxyl radical scavenging flavonoids content and alkaloid of pepper fruit (Dennettia tripetala) were assayed with results obtained shown in Table 2. All analysis was determined in triplicates and results presented in mean and Standard Deviation (SD).

DPPH radical scavenging activity for the extracts of the seeds of ripe pepper fruit was the highest 
$(82.46+0.16 \%)$ and the peel of the ripe pepper fruit recorded the lowest value $(76.95+0.17 \%)$. However, the peel and seeds of the unripe pepper fruit had $80.09+0.30 \%$ and $80.53+0.21 \%$ respectively. Though these values were lower than that had be ascorbic acid $(88.98+0.22 \%)$ a standard antioxidant for scavenging free radicals, all the samples analysed showed that they have radical scavenging abilities which indicated their abilities to donate protons and could serve as a natural antioxidant. Turmeric as well as its active constituent curcumin, have been reported to have high antioxidant activity to inhibits lipid peroxidation and cyclooxygenase activity (Hussain, 2002).

The reducing power of the peel and seeds extracts of the ripe and unripe pepper fruit recorded relatively high values as compared with standard reducing antioxidants butylatedhydroxytoluene (BHT). Ferric $\left(\mathrm{Fe}^{3+}\right)$ was transformed to ferrous $\left(\mathrm{Fe}^{2+}\right)$ in the presence of the various samples and the reference compound BHT to measure the reductive capability. The unripe peel of the fruit indicated highest activity $76.34+0.61 \%$, while the least was recorded for ripe peel part $68.45+0.23 \%$. The standard Butylated hydroxytoluene (BHT) had 66.67+0.43\% with the ripe and unripe seeds having $69.08+2.23 \%$ and $73.66+1.88 \%$ respectively.

Ochuko et al. (2017) reported the reducing power of $3.58 \pm 0.40(\mathrm{mg} / 100 \mathrm{~g})$ for the ethanol extract of Tetrapleura tetraptera fruit peels. The reducing capacity of a compound may serve as a significant indicator of its potential antioxidant activity. However, the activities of antioxidants have been attributed to various mechanisms such as prevention of chain initiation, decomposition of peroxides, reducing capacity and radical scavenging (Yildirim et al. 2000). As shown in Tables 1 , the reducing power of the pepper fruit parts was compared with

Table 1: Qualitative phytochemical screening of the various extracts of the peel and seeds extracts of ripe and unripe Dennetia tripetala

\begin{tabular}{|c|c|c|c|c|c|}
\hline \multicolumn{2}{|c|}{ Parameters } & Methanol & Ethanol & Butanol & Water \\
\hline \multirow{4}{*}{$\begin{array}{c}\text { Alkaloid } \\
\text { (Wagner's Test) }\end{array}$} & (Ripe seed) & + & + & ++ & + \\
\hline & (Ripe peel) & ++ & ++ & + & $\ldots$ \\
\hline & (unripe seed) & + & ++ & ++ & + \\
\hline & (unripe peel) & + & + & ++ & + \\
\hline \multirow{4}{*}{$\begin{array}{c}\text { Terpenoid } \\
\text { (Salkowski'stest) }\end{array}$} & (Ripe seed) & ++ & ++ & +++ & + \\
\hline & (Ripe peel) & +++ & $\ldots$ & ++ & + \\
\hline & (unripe seed) & ++ & ++ & ++ & - \\
\hline & (unripe peel) & ++ & ++ & ++ & + \\
\hline \multirow{4}{*}{$\begin{array}{c}\text { Tannins (Brayer's } \\
\text { Test) }\end{array}$} & (Ripe Seed) & + & + & - & + \\
\hline & (Ripe peel) & - & +++ & + & + \\
\hline & (unripe seed) & + & + & - & _ \\
\hline & (unripe peel) & - & + & - & $\ldots$ \\
\hline \multirow{4}{*}{$\begin{array}{c}\text { Saponin } \\
\text { (Frothing's Test) }\end{array}$} & (Ripe seed) & + & + & + & ++ \\
\hline & (Ripe peel) & + & ++ & ++ & + \\
\hline & (unripe seed) & + & + & + & + \\
\hline & (unripe peel) & ++ & + & - & + \\
\hline \multirow[t]{4}{*}{ Phenol } & (Ripe seed) & + & + & + & + \\
\hline & (Ripe peel) & + & ++ & ++ & + \\
\hline & (unripe seed) & + & ++ & + & + \\
\hline & (unripe peel) & + & + & + & + \\
\hline \multirow{4}{*}{$\begin{array}{c}\text { Flavonoid } \\
\text { (Alkaline Reagent } \\
\text { Test) }\end{array}$} & (Ripe seed) & + & + & + & + \\
\hline & (Ripe peel) & ++ & ++ & + & ++ \\
\hline & (unripe seed) & + & ++ & $\ldots$ & - \\
\hline & (unripe peel) & + & ++ & ++ & + \\
\hline
\end{tabular}


International Journal of Engineering Applied Sciences and Technology, 2020

Vol. 5, Issue 2, ISSN No. 2455-2143, Pages 60-68

Published Online June 2020 in IJEAST (http://www.ijeast.com)

\begin{tabular}{|c|c|c|c|c|c|}
\hline \multirow{4}{*}{$\begin{array}{c}\text { Steroid } \\
\text { (Libermann- } \\
\text { Burchard) }\end{array}$} & (Ripe seed) & - & + & + & \\
\cline { 2 - 6 } & (Ripe peel) & ++ & +++ & ++ & + \\
\cline { 2 - 6 } & (unripe seed) & + & ++ & ++ & + \\
\cline { 2 - 6 } & (unripe peel) & - & - & +++ & + \\
\hline \multirow{4}{*}{ Glycoside } & (Ripe seed) & +++ & ++ & +++ & ++ \\
\cline { 2 - 6 } & (Ripe peel) & +++ & ++ & +++ & ++ \\
\cline { 2 - 6 } & (unripe seed) & ++ & ++ & ++ & ++ \\
\cline { 2 - 6 } & (unripe peel) & +++ & +++ & + & ++ \\
\hline
\end{tabular}

Keys: $+++=$ High abundance,$\quad++=$ Moderate abundance, $+=$ Low abundance, - Not detected

the standard Butylatedhydroxytoluene (BHT) and found to be superior.

The hydrogen peroxide $\left(\mathrm{H}_{2} \mathrm{O}_{2}\right)$ scavenging activity for the ripe and unripe peel and seeds of pepper fruit had $30.67+1.13 \%$ for the unripe peel as highest activity and $5.60+0.62 \%$ was recorded for ripe peel as least value. The ripe and unripe seeds had $5.61+0.79$ and $29.88+1.13 \%$ respectively. However, standard BHT recorded $15.18+0.58 \%$ activity. From the results, it appeared that the $\mathrm{H}_{2} \mathrm{O}_{2}$ scavenging activity of the all the samples compared to that of the standard BHT. Hydrogen peroxide is a weak oxidizing agent that inactivates a few enzymes directly, usually by oxidation of essential thiol (-SH) groups. Ngozi et al. (2014) reported that root extracts of ripe and unripe pepper fruits show that concentration-dependent $\mathrm{H}_{2} \mathrm{O}_{2}$-scavenging capacity which was comparable to that of the ascorbic acid, with an $\mathrm{IC}_{50}$ value of $86.79 \mu \mathrm{g} / \mathrm{ml}$. Iron can stimulate lipid peroxidation by the Fenton reaction $\left(\mathrm{H}_{2} \mathrm{O}_{2}+\right.$ $\mathrm{Fe}^{2+}=\mathrm{Fe}^{3+}+\mathrm{OH}^{-}+\mathrm{OH}$.) and can also accelerate lipid peroxidation by decomposing lipid hydroperoxides into peroxyl and alkoxyl radicals that can perpetuate the chain reaction (Halliwell,

Table 1: Phytochemical and Antioxidants capacities of the peel and seeds extracts of ripe and unripe Dennetia tripetala

\begin{tabular}{|c|c|c|c|c|c|c|c|}
\hline Sample & DPPH (\%) & $\begin{array}{c}\text { Reducing } \\
\text { power }(\boldsymbol{\%})\end{array}$ & $\begin{array}{c}\mathbf{H}_{2} \mathbf{O}_{2} \\
\text { Scavenging } \\
(\%)\end{array}$ & $\begin{array}{c}\text { Total } \\
\text { Phenolic } \\
(\mathbf{m g} / \mathbf{k g} \text { as } \\
\text { gallic acid } \\
\text { equivalent) }\end{array}$ & $\begin{array}{c}\text { Total } \\
\text { flavonoids } \\
(\%)\end{array}$ & $\begin{array}{c}\text { Hydroxyl } \\
\text { radical } \\
\text { scavenging } \\
(\%)\end{array}$ & $\begin{array}{c}\text { Alkaloid } \\
(\mathbf{m g} / \mathbf{1 0 0 g})\end{array}$ \\
\hline Ripe peel & $76.95 \pm 0.17$ & $68.45 \pm 0.23$ & $5.60 \pm 0.62$ & $0.151 \pm 0.01$ & $75.28 \pm 1.35$ & $17.23 \pm 0.58$ & $0.16 \pm 0.02$ \\
\hline Unripe peel & $80.09 \pm 0.30$ & $76.34 \pm 0.61$ & $30.67 \pm 1.13$ & $0.116 \pm 0.00$ & $75.03 \pm 0.94$ & $15.61 \pm 0.58$ & $0.17 \pm 0.02$ \\
\hline Ripe seed & $82.46 \pm 0.16$ & $69.08 \pm 2.23$ & $5.61 \pm 0.79$ & $0.068 \pm 0.00$ & $74.03 \pm 0.78$ & $4.58 \pm 2.02$ & $0.17 \pm 0.02$ \\
\hline Unripe seed & $80.53 \pm 0.21$ & $73.66 \pm 1.88$ & $29.88 \pm 1.13$ & $0.091 \pm 0.00$ & $75.66 \pm 0.38$ & $28.00 \pm 3.40$ & $0.19 \pm 0.01$ \\
\hline Ascorbic acid & $88.98 \pm 0.22$ & - & - & - & - & - & - \\
\hline BHT & - & $66.67 \pm 0.43$ & $15.18 \pm 0.58$ & - & - & - & - \\
\hline
\end{tabular}

Mean \pm SD

1991). Metal chelating capacity is significant since it reduces the concentration of the transition metal that catalyzes lipid peroxidation (Duh et al., 1999).

Hydroxyl radical activities of Dennettia tripetala revealed that the ripe peel had $17.23+0.58 \%$, the unripe peel $15.61+0.58 \%$, the ripe fruit seeds $4.58+2.02 \%$ and the unripe seeds had $28.00+3.40$
$\%$. Hydroxyl radicals are the major active oxygen species causing lipid peroxidation and enormous biological damage. The reduction in the orange colouration after the addition of the samples indication the hydroxyl radical scavenging power as it prevented further reaction.

The Phenolic and flavonoids contents of Dennettia tripetala recorded Phenolic in the range of $0.091+0.00-0.151+0.01 \mathrm{mg} / \mathrm{kg}$ as gallic acid 
equivalent, while flavonoids contents had a range of $74.03+0.78-75.66+0.38 \%$. The total phenolic content value of $212 \mathrm{mg}$ gallic acid equivalent/g obtained for the root extract of Dennettia tripetala has been reported by Ngozi et al. (2014) which was quite higher than values of 1.4 and $1.0 \mathrm{mg} / \mathrm{g}$ reported for the ripe and unripe fruits of the plant respectively reported by Adebayo et al. (2010). Phenolic compounds act as antioxidants through mechanisms which include donation of protons, quenching of singlet oxygen and chelating of metals (Abdel-Hameed, 2012). Polyphenolic compounds are known to have antioxidant activity and it is likely that the activity of the samples is due to these compounds. This activity is believed to be mainly due to their redox properties, which play an important role in adsorbing and neutralizing free radicals, quenching singlet and triplet oxygen, or decomposing peroxides (Zheng and Wang, 2001) thereby preventing DNA oxidative damage and scavenging of reactive oxygen species (ROS), such as superoxide, hydrogen peroxide and hydroxyl radical.

\section{CONCLUSION}

Phytochemicals and antioxidants have been observed in recent study as a vital and important health- improving, that is beneficial to man. The results from this study affirmed that Dennettia tripetala contains significant amount of antioxidant/secondary metabolites at high concentrations with respect to their; alkaloid, tannins, DPPH scavenging activity, reducing power, $\mathrm{H}_{2} \mathrm{O}_{2}$ scavenging, total Phenolic, hydroxyl radical scavenging activities and total flavonoids thereby presenting it as good source for natural antioxidants. Indeed the plant Dennettia tripetala can play a vital role in preventing various diseases. Conclusively, components responsible for the antioxidative activities needed to be studied in order to isolate and identify the specific antioxidant compounds present in the fruit.

\section{REFERENCES}

[1] Thompson, F.E., Willis, G.B., Thompson, O.M. and Yaroch, A.L. (2011). The meaning of fruits and vegetables. Public Health Nutrition, vol. 14, no. 7, (pp. 12221228).
[2] Slavin, J.L. and Lloyd, B. (2012). Health Benefits of Fruits and Vegetables. Advances in Nutrition An International Review Journal, vol. 3, (pp. 506-516).

[3] Molyneux, P. (2004). The use of the stable free radical diphenylpicrylhydrazyl (DPPH) for estimating antioxidant activity. Songklanakarin Journal of Science and Technology, vol. 26, no. 2, (pp. 211 -219).

[4] Ramamoorthy, K.P and Bono, A. (2007). Antioxidant activity, total phenolic and flavonoid content of Morinda citrifolia fruit extracts from various extraction processes. Journal of engineering science and technology, vol. 2, no. 1.

[5] Iseghohi, S.O. (2015). A Review of the Uses and Medicinal Properties of Dennettia tripetala (Pepperfruit). Medical Sciences, vol. 3, (pp. 104-111).

[6] Adedayo, B.C., Oboh, G. and Akindahunsi, A. (2010). Changes in the total phenolic content and antioxidant properties of pepperfruit (Dennettia tripetala) with ripening. African Journal of Food Science, vol. 46, (pp. 403-409).

[7] Elekwa, I., Okereke, S.C. and Chukwudomo, C.S. (2011). Phytochemical screening and GC-MS analysis of the essential oil of Dennettia tripetala (Pepperfruit) seeds. ABSU J. Environ. Sci. Tech., vol. 1, (pp. 93-98).

[8] Okwu, D.E. and Morah, F.N.I. (2004). Mineral and Nutritive value of Dennettia tripetala fruits. Fruits, vol. 59, no. 6, (pp. 437-442).

[9] Ihemeje, A., Ojinnaka, M.C., Obi, K.C. and Ekwe, C.C. (2013). Biochemical evaluation of Pepperfruit (Dennettia tripetala) and its use as substitute for ginger in zobo drink production. Acad. Res. Int., vol. 4, (pp. 513-521).

[10] Sylvia, O.I. (2015). A Review of the Uses and Medicinal Properties of Dennettia tripetala (Pepperfruit). Medical Sciences, vol. 3, no. 4, (pp. 104-111). 
[11] Zhishen, J., Mengcheng, T., and Jianming, W., (1999). The determination of flavonoid content in mulberry and their scavenging effects on superoxide radicals. Food Chemistry, vol. 64, (pp. 555-559).

[12] Awah, F.M., Uzoegwu, P.N., Oyugi, J.O., Rutherford, J., Ifeonu, P., Yao, X., Fowke, K.R., and Eze, M.O., (2010). Free radical scavenging activity and immunomodulatory effect of Stachytarpheta angustifolia leaf extract. Food Chemistry, vol. 119, (pp. 14091416).

[13] Floriano-Sánchez, E., Villanueva, C., Medina-Campos, O.N., Rocha, D., Sánchez-González, D.J., CárdenasRodríguez, N., Pedraza-Chaverrí, J., (2006). Nordihydroguaiaretic acid is a potent in vitro scavenger of peroxynitrite, singlet oxygen, hydroxyl radical, superoxide anion, and hypochlorous acid and prevents in vivo tyrosine nitration in lung. Free Radical Research, vol. 40. (pp. 523-533).

[14] Elizabeth, K. and Rao, M.N.A. (1990). Oxygen radical scavenging activity of curcumin. International Journal of Pharmaceutical, vol. 58, (pp. 237-240).

[15] Oyaizu, M., (1986). Studies on products of browning reactions: antioxidant activities of products of browning reaction prepared from glucose amine. Japanese Journal of Nutrition, vol. 44, (pp. 307-315).

[16] Trease, G.E., Evans, W.C., 2002. Pharmacognosy, fifteenth ed. Saunders, (pp. 214-393).

[17] Obadoni, B. and Ochuko, P., (2001). Phytochemical studies and comparative efficacy of the crude extracts of some homostatic plants in Edo and Delta States of Nigeria. Global Journal of Pure Applied Science, vol. 8, (pp. 203-208).

[18] Hussain, H.E.M.A. (2002). Hypoglycemic, hypolipidemic and antioxidant properties of combination of curcumin from Curcuma longa, Linn and partially purified product from Abroma ugusta, Linn in streptozotocin induced diabetes. Indian Journal of Clinical Biochemistry, vol. 17, no. 2, (pp. 33-43).

[19] Ochuko, L.E., Olayinka, F.O., Benedict, O.O., Tosin, A.O., Temiloluwa, A.A., Adesewa, O.T., Sunday, O.A. and Grace, I.O. (2017). Ethanol extract of Tetrapleura tetraptera fruit peels: Chemicalcharacterization, and antioxidant potentials against free radicals and lipid peroxidation in hepatic tissues. Journal of Taibah University for Science, vol. 11, (pp. 861-867).

[20] Yildirim, A., Mavi, A., Oktay, M. and Karam, A.A. (2000). Algur OF, Bilaloglu V: Comparison of antioxidant and antimicrobial activities of Tilia (Tilia argentea Desf Ex DC), Sage (Savia triloba L.), and Black Tea (Camellia sinensis) extracts. J Agric Food Chem., vol. 48, no. 10, (pp. 5030-5034)

[21] Ngozi, P.O., Abiodun, F. and Oluseyi, D. (2014). Evaluation of the Antioxidant Activity of Root Extract of Pepper Fruit (Dennetia Tripetala), and It's Potential for the Inhibition of Lipid Peroxidation. Africa Journal od Traditional Complement Alternative Medicine, vol. 11, no. 3, (pp. 221-227).

[22] Halliwell, B. (1991). Reactive oxygen species in living systems: source, biochemistry, and role in human disease. America Journal of Medical, vol. 91, no. 3C, (pp. 14S-22S).

[23] Duh, P.D., Tu, Y.Y. and Yen, G.C. (1999). Antioxidant activity of water extract of Harng Jyur (Chrysenthemum morifolium Ramat). Lebnes wiss Technol., vol. 32, (pp. 269-277).

[24] Abdel-hameed, E.S., Salih, A.B. and Shohayeb, M.M. (2012). Total Phenolics and antioxidant activity of defatted fresh taif rose, Saudi Arabia. Br J Pharm Res., vol. 2, (pp. 129-140). 
Published Online June 2020 in IJEAST (http://www.ijeast.com)

[25] Zheng, W., and Wang, S.Y. (2001). Antioxidant activity and phenolic compounds in selected herbs. Journal of Agricultural Food Chemistry, vol. 49, no. 11, (pp. 5165-5170).

[26] Oparanozie, T.I. (2015). Phytochemical quantification, antioxidant and antimicrobial activities of root extracts of Dennettia tripetala and Milica excelsa. M.Sc. Thesis, Department of Pure and Industrial Chemistry, University of Nigeria, Nsukka. (pp 18). 